\title{
Manajemen Komunikasi Pelestarian Budaya Seni Tari Pada Sanggar "Potre Koneng" Kabupaten Sumenep
}

\author{
Hafidlatul Fauzuna \\ Program Studi Komunikasi dan Penyiaran Islam, IAIN Madura \\ Email: fauzunafieda@iainmadura.ac.id
}

\begin{abstract}
Today, the art of dance is being destroyed so that it requires preservation effort, in order to maintain its sustainability in the midst of society. This is what the Potre Koneng dance studio in Sumenep Regency is doing, namely by managing good communication so that efforts to preserve the art of dance take place well. This study uses a qualitative descriptive approach with data collection techniques using interviews, observation and documentation. The result showed that the communication management carried out in the Potre Koneng dance studio used an adult communication model which was analogous to the "Russian Matouschka dolls", which consisted of self doll, interpersonal doll, people-in-system doll, and competence doll components. Self doll was done in the form of contact, involvement and intimacy. Interpersonal doll was done in the form of empathy, supportive attitude, positive attitude, and an equality. The people-in-system doll was depicted by messing with the humanistic design between the Potre Koneng dance studio and the community. Meanwhile, competence doll covers all layers or sizes of the previous doll. The obstacles in communication management at the Pore Koneng dance studio are the noise during practice and the existence of suspicious prejudices.
\end{abstract}

Keywords: communication management; dance art; cultural preservation

\begin{abstract}
Abstrak: Dewasa ini kesenian tari mengalami pemusnahan sehingga membutuhkan upaya pelestarian, guna menjaga keberlangsungannya di tengah-tengah masyarakat. Hal itulah yang dilakukan sanggar tari Potre Koneng di Kabupaten Sumenep, yaitu dengan melakukan manajemen komunikasi yang baik agar upaya pelestarian seni tari berlangsung dengan baik. Penelitian ini menggunakan pendekatan deskriptif kualitatif dengan teknik pengumpulan data menggunakan wawancara, observasi dan dokumentasi. Hasil penelitian menunjukkan bahwa manajemen komunikasi yang dilakukan di sanggar tari Potre Koneng menggunakan model komunikasi orang dewasa yang dianalogikan sebagai "Russian Matouschka dolls", yang terdiri dari komponen self doll, interpersonal doll, people-in-system doll, dan competence doll. Self doll dilakukan dalam bentuk kontak, keterlibatan dan keakraban. Interpersonal doll dilakukan dalam bentuk empati, sikap mendukung, sikap positif, dan sebuah kesetaraan. People-in-system doll digambarkan dengan mengacau pada rancangan humanistik antara sanggar tari Potre Koneng dengan masyarakat. Sementara competence doll meliputi seluruh lapisan atau ukuran boneka sebelumnya. Adapun hambatan-hambatan dalam manajemen komunikasi di sanggar tari Potre Koneng adalah kegaduhan saat latihan dan adanya prasangka curiga.
\end{abstract}

Kata Kunci: manajemen komunikasi; seni tari; pelestarian budaya

\section{Pendahuluan}

Budaya masyarakat Indonesia dewasa ini telah mengalami krisis jika dibandingkan pada zaman dulu. Saat ini masyarakat Indonesia cenderung tidak mencintai budaya sendiri, lebih senang menggunakan produk-produk impor sebagai gaya hidup sehari-hari. Permasalahan yang kemudian muncul adalah pengaruh budaya asing yang kian mengikis nilai-nilai budaya Indonesia. Masuknya budaya asing ke Indonesia tersebut berjalan sangat cepat dan mempengaruhi berbagai bidang kehidupan melalui beragam media. Pengaruh tersebut akan menghasilkan dampak yang sangat luas pada sistem kebudayaan masyarakat. Begitu cepatnya 
pengaruh budaya asing tersebut menyebabkan terjadinya goncangan budaya (culture shock), yaitu suatu keadaan dimana masyarakat tidak mampu menahan berbagai pengaruh kebudayaan yang datang dari luar sehingga terjadi ketidakseimbangan dalam kehidupan masyarakat.

Kebudayaan diyakini sebagai warisan dari orang dewasa kepada anak-anak. Bahwa manusia tidak dilahirkan dengan kebudayaan, tapi kebudayaan itu dipelajari oleh manusia sepanjang kehidupannya. Proses belajar itu merupakan salah satu bentuk 'bawaan sosial' (social heredity), yang dimiliki manusia sejak lahir. Jadi, jika kita ingin mempelajari kebudayaan maka salah satu cara adalah mempelajari bahwa sosial dari sekelompok orang di dalam kebudayaan tertentu (Liliweri, 2007).

Komunikasi dan kebudayaan merupakan dua konsep yang tidak dapat dipisahkan . Pusat perhatian komunikasi dan kebudayaan terletak pada variasi langkah dan cara manusia berkomunikasi melintasi komunkasi manusia atau kelompok sosial. Pelintasan komunkiasi itu menggunakan kode-kode pesan, baik secara verbal maupun non verbal, yang secara alamiah selalu digunakan dalam semua konteks interaksi. Pusat perhatian studi komunikasi dan kebudayaan juga meliputi bagaimana menjajaki makna, pola-pola tindakan, dan bagaimana makna serta pola-pola itu diartikulasi dalam sebuah kelompok sosial, kelompok budaya, kelompok politik, proses pendidikan, bahkan lingkungan teknologi yang melibatkan interaksi antar manusia (Liliweri, 2007).

Salah satu warisan budaya yang kini menghadapi krisis adalah budaya seni tari. Kesenian tari yang kini mengalami kemunduran di tengah arus globalisasi dan modernisasi, tentunya membutuhkan upaya pelestarian, guna menjaga keberlangsungannnya di tengah-tengah masyarakat. Melestarikan kesenian bukan berarti membiarkan tetap tidak berubah. Tetapi menyesuaikan diri dengan zamannya adalah bentuk dari usaha melestarikan tanpa meninggalkan nilai-nilai yang terkandung di dalamnya. Pelestarian tersebut tentunya dilakukan oleh individu tertentu yang mempunyai tekat dan usaha yang gigih untuk terus berusaha mempertahankan kebudayaan seni tari.

Tari adalah pengungkapan lewat gerak yang digayakan dan berkesinambungan yang di dalamnya terdapat unsur keindahan. Seni tari tidak sekedar ungkapan atau ekspresi spontan tatkala senang dan sedih. Tari berkembang sesuai kebutuhan sosial sehingga mempunyai fungsi yang lebih penting dalam kehidupan bermasyarakat. Tari memiliki fungsi sebagai sarana upacara adat dan religi, pertunjukan dalam upacara perburuan, peperangan, kenaikan tahta, pergantian musim, saat tanam dan panen, kelahiran, bahkan dalam kematian. Tari sebagai salah satu aset pariwisata juga turut meningkatkan devisa Negara. Lebih lanjut lagi, seni tari dapat menjadi sarana pemersatu bangsa, media penerangan, media terapi penyembuhan, pembetukan tubuh, sarana kesehatan, bahkan sebagai sarana komunikasi yang mengasyikkan (Guru, 2007).

Seni tari sebagai kearifan lokal merupakan salah satu yang menjadi warisan budaya Madura. Kondisi budaya seni tari di Indonesia saat ini sudah banyak mengalami kemajuan hingga menjadi perhatian dari Negara lain, terbukti dengan banyaknya wisatawan mancanegara yang datang ketika diadakannya festival-festival budaya di tanah air. Namun bagi masyarakat awam atau pedesaan di Madura, khususnya di Sumenep masih kurang begitu menerima perkembangan budaya seni tari. Mereka lebih menyukai tari-tarian tradisi yang merupakan warisan masyarakat secara turun-temurun.

Upaya pelestarian dan pengembangan seni tari salah satunya melalui pendidikan non formal dalam suatu kelompok sanggar. Sanggar adalah suatu tempat atau sarana yang digunakan 
oleh suatu komunitas atau sekumpulan orang untuk melakukan suatu kegiatan. Salah satu sanggar tari yang tergerak untuk melestarikan seni tari adalah sanggar "Pottre Koneng" di Kabupaten Sumenep Madura. Sanggar tersebut didirikan oleh seorang seniman tari yang mendedikasikan dirinya demi mewariskan dan membagikan apa yang telah dia pahami tentang kebudayaan seni tari. Sanggar tari ini didirikan pada tahun 1999 oleh Edi. Bentuk kepeduliannya hingga kini masih dirasakan. Sebab, sanggar yang telah berdiri sekian tahun lalu hingga saat ini masih terbukti eksis dan terus mengadakan aktivitas keseniaannya sampai berhasil membawa anak didikannya mewakili Indonesia ke luar negeri.

Interaksi komunikasi antarpribadi selalu diaplikasikan Edi Susanto dalam sanggar tari "Pottre Koneng" untuk memicu bagaimana interaksi dalam sanggar menjadi produktif, efektif, dan menyenangkan dengan cara berbagi cerita tentang pengalaman pribadinya terhadap kesenian tari yang dia pahami lalu bersama-sama berlatih dan membuat materi, di saat itu lah Edi Susanto menilai karakter setiap anak didiknya, lebih pantas tarian apakah dari masing-masing anak didiknya tersebut. Kemudian setiap tiga bulan sekali selalu diadakan evaluasi bersama dengan para asistennya yang membicarakan tentang ada kendala atau perkembangan apa dari peserta didik, wali, maupun lingkungan masyarakat selama tiga bulan tersebut. Dapat dikatakan, komunikasi antarpribadi sangat penting karena melibatkan personal secara langsung (Azhar, 2018).

Komunikasi merupakan sarana untuk terjalinnya hubungan antar seseorang dengan orang lain, dengan adanya komunikasi maka terjadilah hubungan sosial, karena bahwa manusia itu adalah sebagai makluk sosial yang saling membutuhkan, berdampak pada terjadinya interaksi sehingga mampu memenuhi kebutuhan dalam kehidupan (Rezananda \& Prasetio, 2019). Interaksi ini terjadi apabila orang yang terlibat dalam komunikasi tersebut saling memahami maksud yang terdapat di dalamnya sehingga meningkatkan keharmonisan sebuah hubungan dan human relation (Khumaedi \& Habzah Diniyati, 2020; Kuswanti et al., 2020; Agustin \& Tamburian, 2019). Interaksi tersebut biasanya menggunakan simbol-simbol, yang menurut West \& Turner, simbol-simbol tersebut digunakan untuk menciptakan dan menginterpretasikan makna yang terdapat dalam lingkungan sosial (Yohana \& Rumyeni, 2019). Dalam hubungan seseorang dengan orang lain terjadi proses komunikasi yang tentunya tidak terlepas dari tujuan yang menjadi topik atau pokok pembahasan, tercapainya proses penyampaian informasi tersebut akan dikatakan berhasil apabila ditunjang dengan strategi atau manajemen komunikasi yang baik sebagai sarana penyaluran pesan atau informasi serta untuk mencapai tujukan manajemen komunikasi itu sendiri (Marfu'ah, 2018).

Manajemen komunikasi sangat identik dengan interaksi sosial. Manajemen komunikasi adalah manajemen yang diterapkan dalam kegiatan komunikasi agar tujuan komunikasi tercapai dengan baik (Yohana \& Rumyeni, 2019). Ada kalanya di mana individu harus mampu untuk memposisikan diri dengan tepat dalam situasi tertentu, setiap individu juga harus mampu menghadapi dan menjalin kerjasama dengan orang lain tanpa mencampurnya dengan urusan pribadi. Ini merupakan sebagian alasan diperlukannya sikap profesional dalam diri setiap individu. Manajemen komunikasi juga memberi saran kepada khalayak bahwa kemampuan untuk berkomunikasi dengan baik bukan hanya sebagai hal yang sudah melekat dalam diri saja, melainkan sebagai suatu hal yang dapat dipelajari dan dikembangkan. Dalam perspektif ini, strategi komunikasi menjadi sangat penting dalam mengelola terjalinnya sebuah interaksi dan keberlangsungan sebuah lembaga atau organisasi (Sahputra, 2020). 


\section{Metode Penelitian}

Penelitian ini menggunakan pendekatan deskriptif kualitatif. Riset kualitatif bertujuan untuk menjelaskan fenomena dengan sedalam-dalamnya (Kriyantono, 2006). Pendekatan kualitatif dalam komunikasi menekankan pada bagaimana sebuah pendekatan dapat mengungkapkan makna-makna dari konten komunikasi yang ada sehingga hasil-hasil penelitian yang diperoleh berhubungan dengan pemaknaan dari sebuah proses komunikasi yang terjadi (Bungin, 2008).

Teknik pengumpulan data yang digunakan adalah wawancara mendalam, observasi dan didukung dokumentasi. Wawancara dilakukan secara informal dan menggunakan interview guide untuk kepentingan wawancara yang lebih mendalam. Wawancara informal bersifat terbuka dan longgar sehingga wawancara mirip dengan percakapan (Pawito, 2008). Informan dalam penelitian ini adalah Edi Susanto sebagai seniman dan para aistennya, yaitu Ela, Fifin dan Iik. Materi wawancara adalah tema yang ditanyakan kepada informan (Bungin, 2011).

Observasi merupakan metode pengumpulan data yang digunakan peneliti untuk menghimpun data penelitian melalui pengamatan dan pengindraan (Bungin, 2011). Penelitian manajemen komunikasi pada sanggar tari "Pottre Koneng" ini lebih condong pada observasi tak berstruktur, di mana observasi dilakukan tanpa menggunakan guide observasi.

Teknik analisis data yang digunakan adalah reduksi data (data reduction), penyajian data (data display), dan penarikan serta pengujian kesimpulan (drawing and verifying conclusions) (Pawito, 2008). Unguk mengecek validitas data digunakanlah triangulasi sumber. Trianggulasi sumber dilakukan dengan membandingkan dan mengecek baik derajat kepercayaan suatu informasi yang diperoleh melalui waktu dan cara yang berbeda dalam metode kualitatif yang dilakukan dengan cara: (1) Membandingkan data hasil pengamatan dengan hasil wawancara pada para informan, (2) Membandingkan apa yang dikatakan orang di depan umum dengan apa yang dikatakan secara pribadi oleh para informan, (3) Membandingkan apa yang dikatakan orang tentang situasi penelitian dengan apa yang dikatakan sepanjang waktu, (4) Membandingkan keadaan dan perspektif seseorang dengan berbagai pendapat dan pandangan orang seperti rakyat biasa, orang yang berpendidikan menengah dan tinggi, orang berada, orang pemerintahan, dan (5) Membandingkan hasil wawancara dengan isu yang berkaitan.

\section{Hasil dan Pembahasan}

Sanggar Tari Pottre Koneng berada di Jl. Teuku Umar 23 Desa Pandian Kecamatan Kota Sumenep, didirikan pada tahun 1999. Pada awal-awal berdiri sanggar ini hanya terdiri dari 7 peserta didik hingga kini telah berhasil mendirikan 4 cabang yang ada di Kecamatan Kalianget, Saronggi, Bluto dan di Kecamatan Kota Sumenep sendiri dengan kurang lebih 386 peserta didik dari semua tingkatan usia, mulai dari anak TK, SD, SMP dan SMA. Namun, usia remaja hingga dewasa juga cukup banyak. Bahkan, ada kelompok tari khusus guru yang biasa tampil untuk kegiatan kependidikan dan semacamnya.

Edi Susanto merupakan salah satu seniman di Sumenep yang sejak tahun 1988 tetap menjaga dan melestarikan seni tari di tengah-tengah budaya asing yang mendominasi. Kerja kerasnya dalam menjaga seni budaya membuahkan hasil, sehingga pada Oktober tahun 1999 berhasil mendirikan sanggar tari di kabupaten Sumenep yang masih tetap berdiri hingga saat ini. Edi Susanto mengkolaborasikan seni tari klasik dengan seni budaya modern. Dalam menjaga kelestarian seni budaya tari ini, Edi Susanto lebih sering mengkomunikasikan karyanya dengan 
tema-tema pedesaan. Edi Susanto memilih tema ini, karena menurutnya daerah pedesaan masih jarang dijamah. Keadaan pedesaan yang masih kental dan syarat dengan adat dan budaya nya ini belum banyak terkontaminasi atau dicampuri oleh budaya asing. Karya-karya seni tari dengan tema pedesaan ini, Edi Susanto ciptakan agar masyarakat kembali mengingat kearifan budaya sendiri.

\section{Manajemen Komunikasi Pelestarian Budaya Tari pada Sanggar "Potre Koneng"}

Konsep manajemen komunikasi menjelaskan bahwa kemampuan seseorang berkomunikasi tidak muncul begitu saja ketika dia lahir, melainkan hasil belajar dan mengembangkannya. Dengan demikian manajemen komunikasi adalah suatu istilah yang memberikan kontribusi terhadap pembentukan makna dalam masyarakat, misalnya dalam memaknai pesan orang lain atau gaya komunikasi orang lain. Manajemen komunikasi yang dilakukan sanggar tari "Pottre Koneng" tidaklah banyak namun cukup efektif dalam upaya pelestarian budaya seni tari di Sumenep.

Pelestarian budaya tari yang Sanggar Potre Koneng dilakukan dengan merekrut peserta didik yang tidak hanya anak-anak dan remaja, namun juga diikuti oleh guru TK hingga SD. Peserta didik di sanggar ini sering memenangkan lomba sehingga dengan sendirinya Sanggar Potre Koneng banyak dibicarakan dan orang-orang tertarik untuk ikut melestarikan budaya tari dengan cara masuk dan berlatih di sanggar tersebut.

Dalam melestarikan budaya tari, Sanggar Potre Koneng melakukan komunikasi dengan model komunikasi orang dewasa yang dianalogikan dengan "Russian Matouschka dolls" (Kaye, 1994). Dalam proses komunikasi yang demikian mengandung unsur-unsur yang saling mempengaruhi, yaitu self doll, interpersonal doll, people-in-system doll, dan competence doll. Boneka self (self doll) dapat disebut sebagai komponen intrapersonal dari model manajemen komunikasi. Hal ini dituangkan Edi Susanto dalam upaya mengkomunikasikan pelestarian seni tari dalam bentuk ide. Menurutnya sebuah ide datang sendiri tanpa mengenal waktu dan tempat.

Secara lebih spesifik, self doll berarti peserta didik di sanggar tari Potre Koneng melakukan komunikasi intrapersonal yang mencakup sensasi, persepsi, memori dan berfikir. Pada komponen yang kedua, interpersonal doll, komunikasi yang dilakukan meliputi beberapa bentuk. Pertama, kontak. Kontak merupakan interaksi sosial karena kontak merupakan syarat utama terjadinya aktivitas-aktivitas sosial. Interaksi sosial merupakan hubungan-hubungan sosial yang dinamis. Interaksi sosial tidak akan mungkin terjadi apabila manusia mengadakan hubungan yang langsung dengan sesuatu yang sama sekali tidak berpengaruh terhadap psikologis yang akan bereaksi ketika mendapat stimulus dari sesuatu yang bisa dirasa oleh panca inderanya di mana antara Edi Susanto dan para asitennya memberi arti atau tafsiran pada masing-masing perilakunya yang berwujud pembicaraan, maupun sikap, perasaan-perasaan apa yang ingin disampaikan yang kemudian memberi reaksi terhadap perasaan yang ingin disampaikan oleh masing-masing dari mereka. Terjadinya suatu kontak tidaklah semata-mata tergantung dari tindakan, tetapi juga tanggapan terhadap tindakan tersebut. Dengan adanya kontak komunikasi tersebut, sikap-sikap dan perasaan antara Edi Susanto dan para asistennya dapat saling mengetahui. Hal itu kemudian merupakan bahan untuk menentukan reaksi apa yang dilakukannya.

Kedua, keterlibatan. Keterlibatan merupakan pengambilan bagian atau pengikutsertaan mental dan emosi serta fisik peserta komunikasi antar pribadi, yakni Edi Susanto dan para 
asistennya dalam memberikan respon terhadap kegiatan yang dilaksanakan dalam proses belajar mengajar di sanggar Tari Pottre Koneng serta mendukung pencapaian tujuan dan bertanggung jawab atas keterlibatannya. Edi Susanto selalu melibatkan para asistennya dalam perencanaan, pelaksanaan untuk bersama ikut memikul tanggung jawab sesuai dengan tingkat kematangan dan tingkat kewajibannya. Keterlibatan yang demikian itu menjadi baik dalam bidang-bidang fisik maupun bidang mental serta penentuan kebijaksanaan.

Keterlibatan antara Edi Susanto dan para asistennya di sini berupa pemikiran sumbangan ide dan pendapat untuk menyusun program maupun untuk memperlancar pelaksanaan program serta untuk mewujudkannya dengan memberikan pengalaman dan pengetahuan guna mengembangkan dan melestarikan Sanggar Tari Pottre Koneng. Keterlibatan para asisten dalam proses pelestarian budaya seni tari di sanggar Tari Pottre Koneng sangat penting untuk menciptakan pembelajaran yang aktif, kreatif, dan menyenangkan, dengan demikian tujuan pembelajaran yang sudah direncakan bisa dicapai semaksimal mungkin.

Ketiga, keakraban. Komunikasi antarpribadi yang dilakukan oleh Edi Susanto sebagai seniman terhadap para asistenya tersebut dimaksudkan untuk menciptakan keakraban dan memperoleh kemudahan dalam berkomunikasi. Kedekatan yang terjalin dari komunikasi yang baik ini terjadi karena adanya intensitas pertemuan dan percakapan antara seniman tari degan para asistennya. Sehingga bahan pembicaraannya pun mulai dari masalah seputar bahan atau materi tari yang diajarkan, masalah hubungan dengan peserta didik di sanggar hingga permalahan serius yang terjadi di lingkungan sekitar. Pertemuan dan pembicaraan yang lebih akrab dan dekat selalu dilakukan dan bahkan dilakukan dengan orangtua peserta didik.

Keempat, perusakan. Perusakan hubungan ditandai dengan tidak lagi ada rasa nyaman dalam hubungan yang dijalin. Hubungan terasa semakin menjauh, lebih banyak diam, dan tidak ada lagi proses pengunngkapan diri. Setiap individu mempunyai proses komunikasi yang bertujuan untuk mengenali satu dengan lainnya. Dalam komunikasi harus ada kejelasan dalam berhubungan agar ada tujuan yang pasti, apabila tidak ada tujuan yang jelas akan terjadi hal-hal yang tidak diinginkan. Misalnya kesalahpahaman komunikasi dapat memecahkan hubungan antarpribadi. Terkadang di dalam suatu komunikasi terjadi salah paham dalam interpretasi, respon, dan asumsi. Hal inilah yang membuat suatu kesalahpahaman dalam berkomunikasi sehingga dari kesaahpahaman ini bisa terjadi perusakan suatu komunikasi. Oleh sebab itu Edi Susanto menjalin komunikasi saling pengertian dan memberi kepercayaan terhadap para asistennya untuk menjaga hubungan komunikasi mereka agar tidak terjadi kesalahpahaman yang dapat mengakibatkan perusakan.

Kelima, pemutusan. Pemutusan hubungan dimulai dari perusakan hubungan. Apabila berlanjut maka akan samapai pada pemutusan hubungan. Menurut R.D Nye (Rakhmat, 2011) terdapat lima sumber konflik yang pertama kompetisi di mana salah satu pihak berusaha memperoleh sesuatu dengan mengorbankan orang lain; yang ke dua adalah dominasi di mana salah satu pihak berusaha mengendalikan pihak lain sehingga pihak lain tersebut merasakan hakhaknya dilanggar; yang ke tiga terdapat kegagalan di mana masing-masing individu berusaha menyalahkan individu yang lain apabila tujuaanya tidak tercapai; kemudian yang ke empat adalah provokasi di mana salah satu pihak terus-menerus berbuat sesuatu yang ia ketahui menyinggung perasaan pihak lain; yang terahir adalah perbedaan di mana nilai-kedua pihak tidak sepakat tentang nilai-nilai yang mereka anut. 
Boneka kedua yang menutupi boneka self tersebut adalah boneka interpersonal (interpersonal self). Pada bagian ini titik perhatiannya adalah bagaimana self berhubungan dengan orang lain. Boneka interpersonal ini menggambarkan bagaimana komunikasi antar manusia dapat mempengaruhi satu sama lainnya dan bagaimana mereka berubah sebagai hasil interaksi di antara mereka. Dalam mendukung kelancaran aktivitas di sanggar tari "Pottre Koneng" Edi Susanto memanfaatkan adanya tiga asistennya. Dari hasil observasi dan wawancara, penggunaan bahasa dalam kegiatan komunikasi yang dilakukan Edi Susanto dalam obrolan saat melatih, menyampaikan materi atau celetukan kadang diselipi dengan bahasa daerah Madura yang lebih pas dan mudah diingat.

Dikemukakan oleh Devito (2011) bahwa terdapat lima kualitas umum dalam efektifitas kamunikasi interpersonal, yaitu keterbukaan (openness), empati (empathy), sikap mendukung (supportiveness), sikap positif (postiveness), dan kesetaraan (equality). Keterbukaan (Openness) atau sikap terbuka sangat berpengaruh dalam menumbuhkan komunikasi antarpribadi yang efektif. Keterbukaan antara Edi Susanto dan para asistennya merupakan pengungkapan reaksi atau tanggapan terhadap situasi yang sedang dihadapi. Tidak hanya mengenai permasalahan seputar tari saja, melainkan masalah-masalah lain pun, seperti kekasih atau tunangan, harus dikumunikasikan agar tidak timbul masalah. Selaku seniman Edi Susanto selalu mengajarkan keterbukaan dalam berpendapat dan berekspresi kepada para asistennya karena dengan seperti itu baik peserta didik dan para asistennya akan merasa nyaman dalam melakukan komunikasi antarpribadi.

Empati (empathy) dapat diartikan sebagai menghayati perasaan orang lain atau turut merasakan apa yang dirasakan orang lain. Sikap empati Edi Susanto sebagai seniman yang melatih peserta didik dan para asistennya selalu menempatkan diri dalam suasana perasaan, pikiran dan keinginan para peserta didik dan asistennya sedekat mungkin dengan tujuan apabila rasa empati tersebut tumbuh dalam proses komunikasi antarpribadi mereka, maka suasana hubungan komunikasi akan dapat berkembang dan menumbuhkan sikap saling pengertian. Rasa empati ini juga tidak hanya terjadi dalam proses hubungan komunikasi mengenai permasalahan seni tari saja, melainkan juga dalam kehidupan sehari hari. Seperti di saat ada asisten Edi Susanto yang memiliki masalah di luar sanggar dan tidak mungkin dipaksakan untuk mengajar peserta didiknya dalam keadaan seperti itu karena sedikit banyak keadaan psikologis akan sangat mempengaruhi proses mengajar di sanggar.

Berikutnya adalah sikap mendukung (supportiveness). Komunikasi antarpribadi memerlukan sikap memberi dukungan atau motivasi dari pihak komunikator agar komunikan mau berpartisipasi dalam komunikasi. Dukungan Edi Susanto merupakan pemberian dorongan atau pengobaran semangat kepada para asistennya, sehingga dengan terciptanya sikap saling mendukung tersebut diharapkan komunikasi yang terjalin akan bertahan lama. Sebagai sebuah contoh, ketika ada asisstennya yang bisa mengangantarkan menang lomba tari Edi Susanto menghargainya dengan baik, terlebih lagi ketika para asistennya memiliki karya dan bisa diterima masyarakat.

Saat timbul permasalahan, Edi Susanto selalu mengajak para asistennya berkumpul untuk bekerja sama mencari pemecahan masalah tersebut, dengan tidak mendikte tetapi secara bersama-sama menetapkan tujuan dan memutuskan bagaimana cara mencapainya. Sikap jujur selalu diterapkan agar tidak menyelimuti motif yang terpendam dari para asistennya tersebut. Selain itu sikap profesional disini juga diterapkan untuk meninjau kembali masing-masing 
pendapat, mengakui bahwa manusia tidak luput dari kesalahan sehingga wajar kalau pendapat dan keyakinan dapat berubah.

Hal lain yang menjadi kunci efektifnya komunikasi dalam pelestarian budata tari di Sanggar Potre Koneng adalah sikap positif (postiveness). Sikap positif merupakan kecenderungan seseorang untuk mampu bertindak berdasarkan penilaian yang baik tanpa merasa bersalah yang berlebihan, menerima diri sebagai orang yang penting dan bernilai bagi orang lain, memiliki keyakinan atas kemampuannya untuk mengatasi persoalan, peka terhadap kebutuhan orang lain, pada kebiasaan sosial yang telah diterima, dapat memberi dan menerima pujian tanpa pura-pura memberi dan menerima penghargaan tanpa merasa bersalah. Sikap positif ini harus ada di kedua belah pihak. Harus ada dalam diri sendiri dan komunikan. Karna sikap positif ini diperlukan dalam pewarisan budaya. Dalam penelitian ini adalah seni tari, agar tujuan dari pelestarian budaya yang diomunikasikan melalui seni tari ini dapat terlaksana dengan baik. Terlebih proses pelestarian budaya yang tidak mudah karena banyaknya budaya asing yang sudah menjamur di masyarakat.

Selaku seniman, Edi Susanto bertindak sebagai komunikator yang dominan menunnjukkan sikap positif untuk memberikan penilaian yang positif pada masing-masing diri komunikan yakni para asistennya, bila dalam kegiatan komunikasi antarpribadi mereka saling menunjukkan sikap positif dari hubungan komunikasi tersebut akan muncul suasana menyenangkan karena kesuksesan komunikasi antarpribadi banyak tergantung pada kualitas pandangan dan perasaan diri, positif atau negatif. Pandangan dan perasaan tentang diri yang positif, akan lahir pola perilaku komunikasi antarpribadi yang positif pula.

Sementara itu, kesetaraan (equality) merupakan perasaan sama dengan orang lain, sebagai manusia tidak tinggi atau rendah, walaupun terdapat perbedaan dalam kemampuan tertentu, latar belakang keluarga, tingkat usia atau sikap orang lain terhadapnya. Kesetaraan yang dimaksudkan di sini tidak terjadi secara langsung. Masing masing pihak menyadari bahwa posisi mereka tidaklah setara. Edi Susanto selaku seniman merupakan pihak yang lebih paham mengenai seni tari dibandingkan dengan anak didik dan para asistennya. Persamaan atau kesetaraan di sini adalah sikap Edi Susanto memperlakukan orang lain secara demokratis, tidak menunjukkan diri sendiri lebih tinggi atau lebih baik dari para asistennya karena status, kekuasaan, kemampuan yang lebih dimilikinya. Dalam persamaan tidak mempertegas perbedaan, artinya tidak mengggurui, tetapi berbincang pada tingkat yang sama, yang akhirnya proses komunikasi akan berjalan dengan baik dan lancer.

Boneka ketiga yang menutupi boneka interpersonal adalah boneka "masyarakat di dalam sistem" (people-in-system doll). Pada bagian ini model manajemen komunikasi menekankan perhatian pada pemahaman dan pengaturan budaya pada sistem manusia tersebut. Pada budaya ini terdapat aturan, norma, nilai dan aktivitas yang unik, baik secara terbuka (overt) atau tertutup (covert). Di luar pelatihan tari, Edi Susanto juga selalu mengajari asisten dan semua anak didiknya dengan tatakrama untuk selalu bersikap sopan santun dan ramah baik dalam perbuatan maupun tutur kata kepada setiap orang untuk menumbuhkan citra positif sanggar tari "Potre Koneng" di masyarakat. Sebagai pertimbangan, jika masyarakat di lingkungan sanggar tidak mendukung, maka sangat tidak mungkin Sanggar Potre Koneng bertahan sampai sekarang.

Sedangkan boneka keempat yang meliputi ketiga boneka sebelumnya disebut sebagai boneka kompeten (competence dolls). Model manajemen komunikasi pada lapisan boneka ini bukan sekedar penutup bagi boneka lainnya, tapi meliputi seluruh lapisan atau ukuran boneka 
sebelumnya. Selain itu, dia kompeten memahami dan menampilkan kemampuan (ability) untuk mengubah sistem sosial secara keseluruhan. Sangatlah penting untuk mengerti bahwa model kompetensi ini bukan hanya terlihat sebagai bagian terluar atau sebagai casing saja, melainkan sebagai kompetensi manajemen komunikasi yang bisa terdapat di semua level model "Russian Matouscha doll" ini. Seseorang menjadi kompeten dalam komunikasi intrapersonalnya ketika dia dapat memahami dirinya dan dapat menimbulkan "self control" atau kontrol diri. Seseorang juga dapat terlihat kompeten ketika dia membangun, mengkoordinasi dan menjelaskan makna kepada orang lain. Dan terakhir, seseorang dapat dinyatakan kompeten ketika dia memperlihatkan kemampuan untuk mengubah salah satu sistem yang dia jalankan atau orang lain dalam sistem tersebut.

\section{Hambatan-hambatan dalam Manajemen Komunikasi Pelestarian Budaya Tari pada Sanggar "Potre Koneng"}

Kegigihnya Edi Susanto sebagai seorang seniman yang mengkomunikasikan seni budaya dengan tari ini tidak terlepas dari cemooh dan cibiran masyarakat sekitar. Namun, Edi Susanto menjadikan ini sebagai profesinya, dia merasa miris dengan keadaan di masyarakat yang semakin tidak peduli dengan budaya nya sendiri. dalam hal ini, komunikasi dalam upaya pelestarian budaya tari yang dilakukan Edi Susanto tidak tidak lepas dari gangguan atau hambatan. Hambatan-hambatan ini dapat berbentuk gangguan mekanik (mechanical chanel noise) dan gangguan semantik (semantic noise). Gangguan mekanik ini adalah gangguan yang disebabkan saluran komunikasi atau kegaduhan yang bersifat fisik, sementara gangguan semantik berhubungan dengan kekeliruan dalam menerjemahkan lambang-lambang bahasa yang digunakan dalam berkomunikasi (Effendy, 2003).

Gangguan yang terjadi saat proses penyampaian pesan dari Edi Susanto sebagai komunikator kepada para asistennya sebagai komunikan, mulai dari proses pengiriman hingga proses penerimaan. Dalam proses pengajaran tari, beberapa asisten Edi Susanto kurang bisa berkomunikasi dengan peserta didik sehingga terkadang Edi Susanto turun langsung. Tidak arhanya itu, dia juga mengajarkan bagaimana berkomunikasi dengan mereka. Secara lebih spesifik, gangguan yang kerap terjadi dalam pelestarian budaya tari di Sumenep terutama di Sanggar Tari Potre Koneng adalah jadwal latihan dan mengajar tari terbentur dengan kuliah dan kegiatan lain, karena gurunya adalah mahasiswa yang masih aktif kuliah.

Sementara yang dimaksud dengan gangguan semantik (semantic noise) berkaitan dengan pesan komunikasi yang maknanya menjadi rusak, hal ini dikarenakan pengetahuan di setiap individu, antara komunikator dan komunikan yakni Edi Susanto dan asistennya. Kesulitan yang kerap dialami dalam pelestarian budaya tari di Sanggar Tari Potre Koneng adalah gangguan yang berkaitan dengan pemahaman peserta didik mengenai materi yang disampaikan. Kesulitan dalam hal ini meliputi dua macam, yaitu kesulitan mengenai karakter anak, seperti anak yang cepat tanggap atau mengerti dan anak yang sulit mengerti atau memahami materi yang diperoleh. Peserta didik dikelompokkan berdasarkan karakter masing-masing.

Terkadang cara penyampaian Edi Susanto berbeda dengan beberapa asistennya. Siti Aisyah mengungkapkan bahwa setiap sikap dari seseorang dari gerak tari itu pasti berbeda jd pada saat melatih itu bukan hanya melihat dari ketepatan gerak, sebagainya, tetapi juga sikap yag harus dimiliki oleh siswa, sikap gagah, lemah lembut, genit dan terkadang juga ada sedikit perbedaan antara gerakan dengan musik. Ketika penyampaian dan penerimaan pesan, maka 
pesan bisa berubah karena perbedaan penilaian terhadap makna dan isi pesan. Hal ini tergantung dari orang yang menginterpretasikannya, hal ini juga dapat membuat misunderstanding dan miscommunication. Dengan demikian, terkadang meskipun makna yang ingin disampaikan begitu baik dan substantif, namun karena tidak disampaikan dengan cara yang baik, maka komunikasi tersebut berpotensi menimbulkan kesalahpahaman. Itu artinya, sebaik-baiknya pesan yang ingin disampaikan, namun jika tidak dikemas dengan baik maka pesan tersebut akan mengalami distorsi makna. Itulah yang memungkinkan kenapa hampir setiap orang memiliki pemaknaan sendiri-sendiri yang berbeda satu sama lain. Dalam paradigma kritis, setiap orang memiliki kerangka pemahaman sendiri-sendiri, sehingga interpretasinya terhadap satu pesan yang sama tetap akan terlihat bebreda

Selain daripada itu, kepentingan komunikator yang tidak memperhatikan kepentingan komunikan akan terjadi ketidak seimbangan antara keduanya, sehingga komunikan hanya akan mau melakukan komunikasi apabila ada kepentingan yang berkaitan dengannya. Kepentingan bukan hanya mempengaruhi kita tetapi juga menentukan daya tanggap, perasaan, pikiran, dan tingkah laku yang akan merupakan sikap reaktif terhadap segala perangsang yang tidak bersesuaian atau bertentangan dengan suatu kepentingan. Hal lain yang dapat menjadi gangguan terhadap efektifitas manajemen komunikasi adalah adanya motivasi terpendam. Motivasi terpendam adalah dorongan seseorang untuk mencapai tujuan, keinginan maupun kebutuhannya, sehingga apabila komunikasi sesuai dengan motivasi seseorang terutama komunikan, maka komunikasi akan dapat berjalan secara efektif. Sebaliknya apabila komunikasi tidak sesuai dengan motivasi yang terpendam dalam diri komunikan, maka komunikasinya mengalami hambatan. Itulah sebabnya, walaupun motivasi setiap orang berbeda, namun demikian ketidaksamaan motivasi terutama dalam melakukan sesuatu akan menjadi titik tolak gagalnya sebuah interaksi atau komunikasi.

Dalam konteks ini sudah jelas bahwa motivasi Edi Susanto menjadi seniman adalah untuk melestarikan budaya asli Madura dengan mengkomunikasikannya melalui seni tari. Motivasi Edi Susanto ini sudah dibuktikan dengan pendirian sanggar tari "Pottre Koneng". Tentu saja hal ini didasarkan pada bahwa budaya Madura, menurut pengakuan Edi Susanto, adalah budaya yang sangat luar biasa. Terlebih lagi warisan nenek moyang memang patut untuk dilestarikan dan dijaga eksistensinya. Motivasi terpendam tidak hanya dipaparkan dan terlihat jelas pada satu narasumber saja yaitu Edi Susanto sebagai narasumber utama yanng berperan sebagai seniman. Motivasi untuk turut melestarikan budaya yang terdapat dalam diri asisten tari Edi Susanto, salah satunya adalah Ella. Mahasiswi dari jurusan Matematika STKIP Sumenep yang menjadi asisten tari Edi Susanto semenjak tahun 2010 ini pun mengatakan motif tersembunyinya bahwa dia memang memiliki kegemaran yang luar biasa besar pada kesenian. Dengan bergabung di sanggar tari Potre Koneng dia dapat menyalurkan berbagai ilmu tentang seni tari tradisi khususnya di kota Sumenep. Ella juga ingin memperkenalkan seni tari tradisi kota Sumenep ke kota-kota lain atau kepada masyarakat luas. Sedangkan asisten lainnya yang bernama Fifin, yang sudah menjadi asisten Edi Susanto sejak tahun 2011, mengungkapkan bahwa keberadaannya di sanggar tari Potre Koneng adalah untuk mengetahui macam-macam tari yang berasal dari daerah mana saja. Alasan yang paling kuat adalah bahwa tari memang hobi Ella dan oleh sebab itu dia ingin meneruskan budaya bangsa supaya tidak hilang dari generasi muda. 
Berikutnya, yang menjadi kendala atau gangguan dalam manajemen komunikasi pelestarian budaya tari di sanggar tari Potre Koneng adalah prasangka (prejudice). Prasangka merupakan salah satu rintangan yang berat dalam berkomunikasi, karena ada komunikan yang memiliki prasangka terhadap komunikator, maka kecurigaan komunikan kepada komunikator akan menjadi penghambat. Selain itu juga adanya sikap menentang dan berburuk sangka kepada komunikator bisa memperburuk keadaan, tetapi apabila komunikator mampu memberi kesan yang baik dan mampu meyakinkan komunikan, maka komunikasi dapat berjalan efektif.

Dalam sebuah komunitas apalagi dalam level yang lebih besar, masyarakat, misalnya, selisih pendapat adalah sesuatu yang pasti. Namun demikian, hal itu juga menjadi sebuah kewajaran. Ada berbagai macam hal yang tidak bisa disamaratakan, terutama di sanggar tari Potre Koneng. Perselisihan pendapat, keterlambatan datang ke sanggar dan hal-hal lainnya masih kerap terjadi. Kesalahpahaman dalam mengartikan sesuatu yang terjadi dalam percakapan atau yang terjadi dalam komunikasi antar pribadi antara Edi Susanto dengan asisten tarinya merupakan salah satu prasangka yang terjadi dalam komunikasi antarpribadi yang terjalin di antara keduanya. Prasangka kerap menjadi faktor gagalnya sebuah hubungan atau interaksi sosial antar dua manusia atau dalam suatu masyarakat. Prasangka pada dasarnya bersumber dari kekeliruan dalam mendefinisikan reaksi yang disampaikan lawan bicara. Hal ini pada gilirannya melahirkan kesalahpahaman dalam interaksi sosial bahkan sebelum pesan itu sampai kepada dan diterjemahkan oleh si penerima pesan.

\section{Kesimpulan}

Dalam metode manajemen komunikasi terdapat metode yang disebut "Boneka Matouschka Rusia” (Russian motouschka dolls) yang memiliki empat ukuran. Boneka pertama merupakan komponen intrapersonal yang memiliki tahapan-tahapan seperti kontak, keterlibatan dan keakraban. Dalam tahapan kontak, baik kepada peserta didik, tim pengajar maupun kepada masyarakat, sanggar tari "Potre Koneng" selalu melakukan kontak langsung atau saling bertatap muka sehingga mempermudah untuk mengetahui feedback secara langsung dari peserta didik, tim pengajar maupun masyarakat itu sendiri. Setelah tahapan kontak terjadi, maka akan memasuki tahapan yang lebih mendalam yaitu keterlibatan.

Boneka kedua ini digambarkan dengan boneka interpersonal di mana terdapat efektifitas komunikasi yang merujuk pada 4 (empat) poin yakni, empati, sikap mendukung, sikap positif, dan sebuah kesetaraan. Sedangkan pada boneka ketiga dalam efektifitas komunikasi digambarkan dengan (human system) yang mengacu pada ancangan humanistik antara Sanggar Tari "Potre Koneng" dengan masyarakat. Masyarakat sekitar memberikan respon positif serta dukungan terhadap pendirian sanggar tari "Potre Koneng" dengan ikut andil membantu ketika sanggar tari "Potre Koneng" ketika mengadakan pagelaran dan lain sebagainya. Boneka yang terahir yakni (competence dolls) yang meliputi seluruh lapisan atau ukuran boneka sebelumnya. Manajemen komunikasi yang dilakukan sanggar tari "Potre Koneng" tidak jarang mengalami hambatan. Hambatan yang diemukan oleh peneliti dalam penelitian ini di antaranya adalah gangguan seperti egaduhan disaat latihan, serta adanya prasangka curiga.

\section{Daftar Pustaka}

Agustin, A., \& Tamburian, H. H. D. (2019). Komunikasi Antarpribadi Antara Mertua dan Menantu Beda Agama. Koneksi, 2(2), 210-217. https://doi.org/10.24912/kn.v2i2.3887 
Azhar, A. (2018). KOMUNIKASI ANTARPRIBADI: Suatu Kajian dalam Perspektif Komunikasi Islam. AL-HIKMAH: Media Dakwah, Komunikasi, Sosial Dan Budaya, 8(1), 79-91. https://doi.org/10.32505/hikmah.v8i1.400

Bungin, B. (2008). Sosiologi Komunikasi. Kencana Prenada Media Group.

Bungin, B. (2011). Penelitian Kualitatif: Komunikasi, Ekonomi, Kebijakan Publik, dan Ilmu Sosial Lainnya. Kencana Prenada media Group.

Devito, J. A. (2011). Komunikasi Antarmanusia, Edisi Kelima. Karisma Publishing Group.

Effendy, O. U. (2003). Ilmu, Teori dan Filsafat Komunikasi. Citra Aditya Bakti.

Guru, T. A. (2007). Seni Budaya. Erlangga.

Kaye, M. (1994). Communication Management. Pretince Hall.

Khumaedi, T., \& Habzah Diniyati, S. (2020). Komunikasi Islam dalam Perspektif Mahasiswa Islam. Al-Mubin; Islamic Scientific Journal, 3(2), 12-18. https://doi.org/10.51192/almubin.v3i2.74

Kriyantono, R. (2006). Teknik Praktis Riset Komunikasi: Disertai Contoh Praktis Riset Media, Publick Relation, Advertising, Komunikasi Organisasi. Kencana.

Kuswanti, A., Muqsith, M. A., Zainal, A. G., \& Oktarina, S. (2020). Manajemen Komunikasi Keluarga Saat Pandemi Covid-19. SALAM: Jurnal Sosial Dan Budaya Syar-I, 7(8), 707722. https://doi.org/10.15408/sjsbs.v7i8.15959

Liliweri, A. (2007). Makna Budaya dalam Komunikasi Antarbudaya. LKiS.

Marfu'ah, U. (2018). Strategi Komunikasi Dakwah Berbasis Multikultural. Islamic Communication Journal, $2(2)$, $147-161$.

https://doi.org/10.21580/icj.2017.2.2.2166

Pawito. (2008). Penelitian Komunikasi Kualitatif. LKis.

Rakhmat, J. (2011). Psikologi Komunikasi (Kedua Pulu). Remaja Rosdakarya.

Rezananda, A., \& Prasetio, A. (2019). Manajemen Komunikasi di Call Center Telkom 147 Kota Semarang. Jurnal Manajemen Komunikasi, $\quad 2(1), \quad 1-9$. https://doi.org/10.24198/jmk.v2i1.11816

Sahputra, D. (2020). Manajemen Komunikasi Suatu Pendekatan Komunikasi. JURNAL SIMBOLIKA: Research and Learning in Communication Study, 6(2), 152-162. https://doi.org/10.31289/simbollika.v6i2.4069

Yohana, N., \& Rumyeni, Y. (2019). Manajemen Komunikasi Dinas Pariwisata Kebudayaan, Kepemudaan dan Olahraga dalam Mengembangkan Potensi Desa Wisata di Kabupaten Bengkalis. Jurnal Komunikasi, 13(1), 1-12. https://doi.org/10.21107/ilkom.v13i1.5211 